In conclusion, he would express his indebtedness to the various gentlemen who have been kind enough to give him the benefit of their criticism and advice upon different points, with regard to which his own special knowledge was insufficient, and also to those others who have assisted him in the matter of references, etc.

University College of N. Wales, Bangor, March 1891.

\title{
AUTHOR'S NOTE TO THE ENGLISH EDITION
}

IT was a great satisfaction to me that the translation of this history was undertaken by my former pupil, Dr. M'Gowan, and I desire to express here my appreciation of the manner in which he has entered into the spirit of the work, and to offer him my hearty thanks for all his trouble in the matter.

May the book find many friends among the Englishspeaking peoples, and help to stimulate the interest of its readers in the development of our science.

ERNST VON MEYER.

LeIPZIG, February 1891. 